\title{
Zdeňka Strašilová
}

\section{Proměny veřejných prostranství}

Klíčová slova: Veřejný prostor; Územní plánování; Placemaking.

Kontakt: zdenka@strasil.net

Školitel: Gabriel Kopáčik

Tematický okruh: Urbanismus

\section{Transformations of Public Spaces}

In Czech towns and cities, public space has become a widely discussed topic, with growing social demand for high-quality public spaces. In spite of this, we still often see public spaces - both new and created by transformation of existing ones - that do not fulfil their purpose and lack sufficient quality, despite significant spending.

Yet the successful functioning of a public space is the main indicator of its quality. Today, leading world theoreticians agree that public spaces need to be adapted to people visiting them, and should provide room for social activities. 
Veřejný prostor je v prostředí českých měst dnes již aktuální téma; společenská poptávka po kvalitních veřejných prostranstvích roste, ovšem přesto jsme svědky realizací mnohých veřejných prostorů, at už nově vzniklých nebo rekonstrukcí těch stávajících, které ani po vynaložení značných nákladů neplní úspěšně svůj účel a nemají dostatečnou kvalitu.

Úspěšnost veřejných prostranství je přitom hlavním indikátorem kvality. V současnosti je převažujícím názorem předních světových teoretiků nutnost tvořit veřejná prostranství přizpůsobená pobytu lidí a poskytující možnost společenských aktivit.

Přesto ve většině případů není hned na počátku projektů jasně definována kvalita veřejného prostoru v celé šiři jeho problematiky. Projekty se zpravidla omezují na fyzickou stránku prostředí, na obnovu povrchů, rozmístění a design mobiliáře a zeleně. Estetická stránka je ale pouze jednou složkou kvalitního veřejného prostoru. Představa o faktorech, které formují veřejné prostory, se v současnosti aktualizuje o nabídku různých funkčních náplní prostorů. Zásadní roli v otázce kvality hraje rovněž vztah veřejných prostorů a hmot urbánních celků, které je vymezují.

Zároveň projekty se silným konceptem, který zohledňuje všechny aspekty kvalitního veřejného prostoru, mohou být problematicky realizovatelné v rámci českého prostředí a právního systému, protože vyžadují změnu některých dosud zavedených př́stupů od direktivního, definitivního řešení směrem $\mathrm{k}$ otevřenějšímu přístupu.

Cílem práce není hledat v problematice kvality veřejných prostranství revoluční myšlenky a originální koncepty. Naopak, současný stav poznání a směr vývoje jsou v souladu s potřebami soudobé společnosti, ovšem chybí nástroje implementace myšlenek v českém prostředí.

Práce si tedy klade za cíl přispět k realizovatelnosti kvalitních veřejných prostranství poskytnutím přehledu zahraničních přístupů k procesu vzniku vhodných referenčních příkladů.

Analýza úspěšných realizací ze tří zahraničních měst - New Yorku (občanské iniciativy, POPS), Kodaně (dopravní řešení) a Vídně (územní plánování) - má poskytnout odpovědi na tři otázky - co činí veřejná prostranství úspěšnými, jak vznikají a jaké nástroje mohou různí aktéři použít a jak lze tyto poznatky aplikovat v českém prostředí.

\section{SOUPIS ZDROJU゚}

BLUE, Elly. Bikenomics: [how bicycling can save the economy]. 1st pub. Portland: Microcosm, 2013, 191 s. ISBN 978-1-62106-003-1. 
GEHL, Jan. Život mezi budovami: užívání veřejných prostranství. Vyd. 1. Brno: Nadace Partnerství, 2000, 202 s. ISBN 80-858-3479-0.

KOUCKÝ, Roman. Elementární urbanismus. Vyd. 1. Praha: Zlatý řez, 2006, 263 s. ISBN 80-902-8109-5.

KRATOCHVÍL, Petr (ed.). Architektura a veřejný prostor: texty o moderní a současné architektuře IV. Vyd. 1. Praha: Zlatý řez, 2012, 164 s. ISBN 978-80-903826-4-0.

SPECK, Jeff. Walkable city: how downtown can save America, one step at a time. First paperback edition. New York: Farrar, Straus and Giroux North Point Press, 2012, 312 pages. ISBN 08- 654-7772-8.

\section{OBRAZOVÉ P̌̌ÍLOHY}

[1] Gehl Architects. Proměny aktivit ve veřejných prostranstvích. [grafika]. Praha: Konference O územním rozvoji, 2013.

[2] STRAŠILOVÁ, Zdeňka. Veřejný prostor jako katalyzátor rozvoje. [archiv autorky]. 2015. 


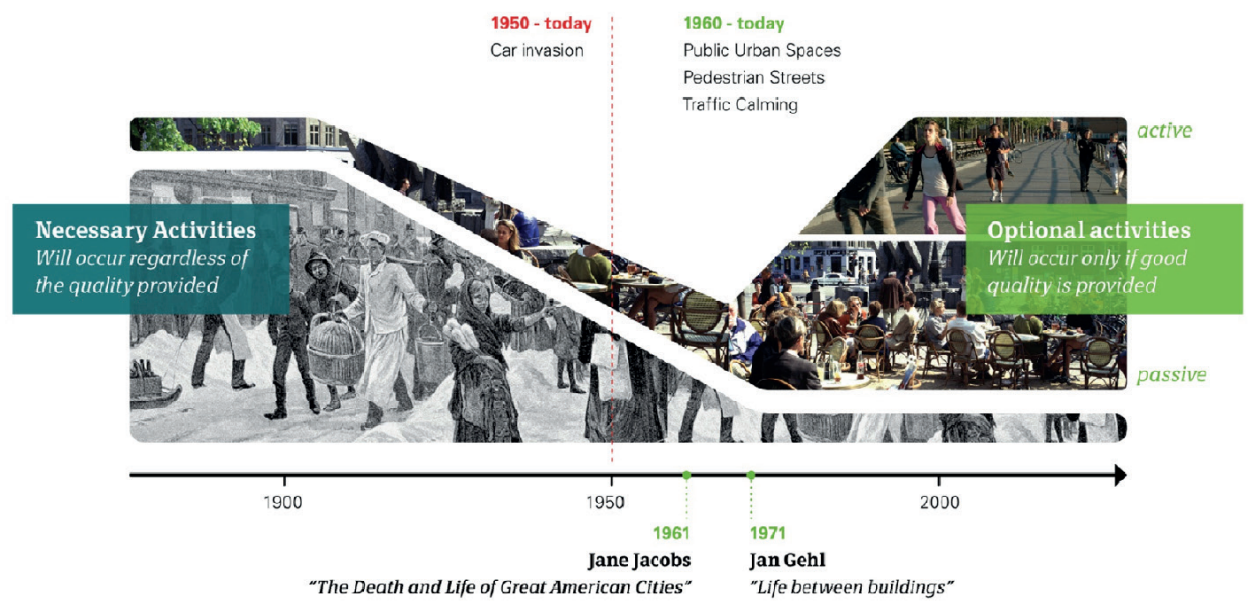

Diagram showing the relation between necessary and optional activities ove- the course of 100 years.

Note the arrival of the car in the mid-fifties and the current intemational trend of providing space for optional public life.

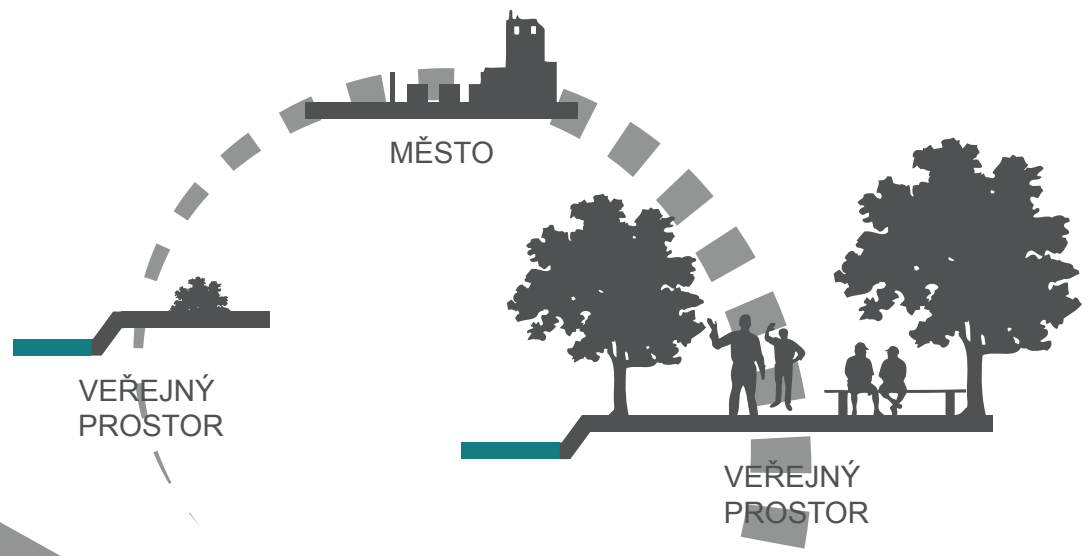

